JIA (Jurnal Ilmiah Akuntansi) • Vol. 6, No. 1, Hal: 164-181 • Juni 2021 $\triangle$ ]

\title{
Keterbacaan Informasi Naratif Laporan Tahunan dan Cash Holdings
}

\author{
Annisaa Rahman*, Rayna Kartika \\ Universitas Andalas, Limau Manis Kec. Pauh, Kota Padang, Sumatera Barat, \\ Indonesia \\ *(annisaa.rahman@gmail.com)
}

Riwayat Artikel:

Tanggal diajukan:

13 November 2020

Tanggal diterima:

10 Juni 2021

Tanggal dipublikasi daring:

25 Juni 2021

Kata kunci: cash holdings; laporan tahunan; keterbacaan

\section{Pengutipan:}

Rahma, Annisaa \& Kartika, Rayna Kartika. (2021). Keterbacaan Informasi Naratif Laporan Tahunan dan Cash Holdings. JIA (Jurnal Ilmiah Akuntansi), Vol. 6, No. 1, Hal: 164-181.

Keywords: annual report; cash holdings; readability

\begin{abstract}
ABSTRAK
Penelitian ini bertujuan untuk menguji dan menganalisis pengaruh keterbacaan informasi naratif laporan tahunan terhadap kebijakan memegang kas perusahaan. Keterbacaan laporan diukur dengan Gunning Fog Index, sedangkan cash holdings diukur dengan rasio kas terhadap total asset perusahaan. Penelitian ini dilakukan dalam periode 2015 sampai dengan 2017. Populasi penelitian ini adalah seluruh perusahaan non keuangan yang terdaftar di Bursa Efek Indonesia. Teknik pengambilan sampel menggunakan purposive sampling dan terpilih 712 perusahaantahun. Analisis data penelitian ini menggunakan regresi linear berganda. Hasil dari penelitian ini menunjukkan bahwa keterbacaan laporan tahunan perusahaan berpengaruh terhadap kebijakan kas yang dipegang perusahaan. Semakin sulit laporan tahunan dibaca, semakin besar jumlah kas yang dipegang oleh perusahaan. Temuan penelitian ini sejalan dengan motif precautionary dan motif agensi yang melandasi perusahaan memegang kas. Temuan penelitian ini secara ringkas menunjukkan dukungan atas dampak keterbacaan laporan tahunan terhadap kebijakan keuangan internal perusahaan.
\end{abstract}

\section{ABSTRACT}

This research aims to test and analyze the effect of readability narrative information of the annual report on cash holdings. The readability is measured by the Gunning Fog Index, while cash holdings are measured by the ratio of cash to total assets. The study was conducted in the period 2015 to 2017. The population of this study is all non financial sector companies listed on the Indonesia Stock Exchange. Sampling techniques used purposive sampling and selected 712 firm-year. Data analysis uses multiple linear regressions. The results show that the readability of the company's annual report affects the companies' cash holdings. The harder the annual report is read, the greater the amount of cash held by the company. The findings of this study are in line with precautionary and agency motives. The findings of this study briefly show support for the readability of annual reports on the company's internal financial policies. 


\section{PENDAHULUAN}

Sifat tekstual pengungkapan narasi, yaitu panjang dan kompleksitas narasi, telah banyak menarik minat penelitian dalam literatur akuntansi dan keuangan (Hasan \& Habib, 2020); (Ertugrul et al., 2017); (Li, 2008). Pengungkapan narasi merupakan instrumen penting yang tidak hanya bermanfaat mengkomunikasikan nilai informasi yang relevan bagi pelaku pasar, tetapi juga berfungsi untuk melakukan pemantauan kegiatan manajerial (Ertugrul et al., 2017); (Loughran \& Mcdonald, 2011). Studi-studi yang telah ada menunjukkan bahwa keterbacaan dari pengungkapan narasi mempengaruhi harga aset perusahaan, beban pembiayaan eksternal, dan volume perdagangan (Loughran \& Mcdonald, 2011); (Lang, M., Stice-Lawrence, 2015); (Loughran \& Mcdonald, 2011), kredibilitas di pasar utang (Bonsall \& Miller, 2017); (Ertugrul et al., 2017), cakupan dan akurasi prakiraan analis (Lehavy et al., 2011), dan efisiensi investasi (Biddle et al., 2009).

Loughran \& Mcdonald (2011) menunjukkan bahwa keterbacaan yang buruk mencerminkan lingkungan informasi yang menyimpang, dan mempengaruhi volatilitas laba dan perkiraan analis. Meskipun demikian, sejauh mana keterbacaan pengungkapan narasi perusahaan berkaitan dengan likuiditas perusahaan, belum banyak tergali. Padahal, dalam kondisi ketidakpastian ekonomi yang tinggi saat ini, likuiditas perusahaan dalam bentuk kecukupan kas yang dipegang perusahaan, diyakini dapat memberi ruang bagi perusahaan dalam meraih keunggulan dan menentukan lintasan pertumbuhan jangka panjang perusahaan.

Celah riset ini perlu digali dengan menguji apakah keterbacaan pengungkapan narasi perusahaan berkaitan dengan uang yang dipegang perusahaan (cash holding), karena cash holding merupakan kebijakan perusahan yang memiliki konsekuensi ekonomi cukup besar. Dari literatur yang ada, telah banyak yang menguji bagaimana keterbacaan pengungkapan perusahaan mempengaruhi kepentingan ekternal, namun masih sedikit yang menggali bagaimana keterbacaan penggungkapan naratif perusahaan berkaitan dengan kebijakan keuangan internal. Selain itu, menggali hubungan antar keterbacaan penggungkapan naratif dengan kebijakan keuangan perusahaan penting karena berimplikasi terhadap kekayaan pemegang saham. 
Literatur terdahulu telah mengidentifikasi sejumlah motif memegang uang kas (cash holdings) perusahaan. Pertama, motif transaksi; menyatakan bahwa manajer memegang kas untuk melakukan pembayaran agar tidak melikuidasi aset atau mencari pembiayaan eksternal yang mahal. Kedua, motif spekulasi; perusahaan akan menggunakan kas untuk berspekulasi mengamati berbagai kesempatan bisnis baru yang dianggap menguntungkan di masa depan.

Ketiga, motif pencegahan (precautionary); menunjukkan bahwa perusahaan memegang kas untuk melindungi perusahaan dari guncangan yang merugikan jika dihadapkan pada pembiayaan eksternal yang mahal (Almeida et al., 2004); (Han \& Qiu, 2007). Keempat, motif agensi; kebijakan memegang kas perusahaan didorong oleh perilaku mementingkan diri manajerial dengan menimbun lebih banyak uang sehingga manajer dapat mengambil manfaat pribadi (Dittmar \& Mahrt-Smith, 2007).

Studi menunjukkan bahwa manajer memiliki insentif untuk menghasilkan pengungkapan narasi yang lebih panjang dan/atau kurang dapat dibaca agar pemantauan kegiatan mereka sulit dilakukan dan berbiaya mahal (Lo et al., 2017). Keburaman informasi ini membuat relatif mudah bagi manajer melakukan salah alokasi sumber daya perusahaan untuk mementingkan diri sendiri (Biddle et al., 2009). Berdasarkan motif agensi, pada saat manajer perusahaan memiliki kesempatan mengungkapkan laporan keuangan dengan lebih panjang dan /atau kurang dapat dibaca untuk memanfaatkan sumber daya perusahaan secara oportunistik (Huang \& Zhang, 2012); (Huang \& Zhang, 2012), maka akan terdapat kecenderungan perusahaan tersebut menimbun lebih banyak kas. Penelitian Ertugrul et al. (2017) juga menunjukkan bahwa berdasarkan motif precautionary (pencegahan), pengungkapan yang kurang dapat dibaca menyebabkan kendala pendanaan yang lebih besar dan risiko atas pembiayaan kembali, sehingga dampak negatif ini meningkatkan kepemilikan kas perusahaan (Almeida et al., 2004) ; (Harford et al., 2014).

Pada penelitian ini, Indek Fog akan digunakan untuk mengukur keterbacaan informasi naratif laporan Management Discussion and Analysis (MD\&A), sebagai komponen dari laporan tahunan perusahaan. Kepemilikan kas (cash holdings) 
perusahaan diukur menggunakan saldo kas dan setara kas perusahaan (Hasan \& Habib, 2020). Penelitian dilakukan pada tahun 2015 sampai 2017

Penelitian ini diharapkan dapat memberikan kontribusi pada pengungkapan narasi perusahaan dan literatur keuangan korporat dalam beberapa hal. Pertama, penelitian ini mengusulkan bahwa keterbacaan pengungkapan naratif berkaitan dengan likuiditas perusahaan. Literatur sebelumnya menunjukkan bahwa keterbacaan pengungkapan naratif perusahaan mempengaruhi persepsi pemangku kepentingan eksternal terhadap perusahaan (Bonsall \& Miller, 2017); (Ertugrul et al., 2017); (Loughran \& Mcdonald, 2011). Penelitian ini menambahkan perspektif baru pada literatur ini dengan menguji keterbacaan pengungkapan naratif apakah berkaitan dengan kebijakan internal keuangan perusahaan. Kedua, penelitian ini mengintegrasikan dua literatur berbeda terkait kebijakan keuangan perusahaan dan literasi lingustik. Terakhir, secara umum penelitian ini memperluas literatur yang meneliti konsekuensi dari pengungkapan naratif dalam laporan tahunan (Biddle et al., 2009); (Ertugrul et al.,
2017); (Lang, M., Stice-Lawrence, 2015); (Loughran \& Mcdonald, 2011).

\section{TELAAH LITERATUR DAN PERUMUSAN HIPOTESIS \\ Keterbacaan Laporan}

Merujuk pada Kamus Besar Bahasa Indonesia, keterbacaan merupakan suatu kondisi di mana wacana dapat dibaca secara cepat, mudah diingat dan dipahami. Dale \& Chall (1948) mendefinisikan keterbacaan sebagai jumlah total semua elemen dalam material yang tercetak yang dapat membuat sekelompok pembaca memahami material tersebut, membacanya dalam kecepatan yang optimal dan material tersebut menarik untuk dibaca.

Pendapat mengenai pengertian keterbacaan dikemukakan oleh DuBay (2004) yang mana keterbacaan menyebabkan teks lebih mudah dibaca. Klare (1963) dan DuBay (2004) mendefinisikan keterbacaan sebagai mudahnya pemahaman atau komprehensif karena gaya penulisan. DuBay (2004) menyatakan bahwa keterbacaan yaitu kemudahan dalam membaca kata-kata dan kalimat.

Terdapat beberapa asumsi tertentu yang diwariskan oleh para penulis dan editor profesional terkait keterbacaan suatu tulisan (Connatser, 1999), yaitu: 
a. Kalimat yang pendek lebih mudah dibaca daripada kalimat panjang.

b. Kata-kata dengan suku kata yang sedikit lebih mudah dibaca daripada kata-kata dengan suku kata yang banyak.

c. Kata-kata yang pendek lebih mudah dibaca daripada katakata yang panjang.

d. Kalimat aktif lebih mudah dibaca daripada kalimat pasif.

Untuk mengukur keterbacaan dari suatu tulisan, diperlukan formula yang dapat digunakan untuk menentukan apakah suatu tulisan dapat dibaca dan dipahami atau tidak. Formula keterbacaan dirancang untuk memprediksi tingkat kesulitan pembaca terhadap suatu tulisan (Connatser, 1999). Alat ukur ini sering disebut sebagai Indeks Fog.

\section{Kas yang Dipegang (Cash Holding)}

Kas merupakan aktiva yang sangat likuid di dalam perusahaan. Kas merupakan uang tunai yang dimiliki oleh perusahaan untuk pembiayaan kegiatan operasional perusahaan. Kas dapat digunakan sebagai pembayaran gaji atau upah karyawan, pembelian aset tetap, pembayaran utang dan dividen dan beberapa transaksi lain yang diperlukan perusahaan. Cash holding merupakan kas yang tersedia untuk dapat diinvestasikan dalam bentuk aset fisik maupun dibagikan ke pada investor sebagai dividen. Cash holding dilihat sebagai kas dan ekuivalen kas yang dapat dengan mudah diubah menjadi uang tunai. Dari pernyataan di atas dapat ditarik kesimpulan bahwa cash holding adalah kas yang tersedia di dalam perusahaan yang digunakan untuk kegiatan operasional, kebutuhan dana yang tidak terduga dan dana investasi.

Motif perusahaan dalam memegang kas yang diungkapkan oleh Bates et al. (2009) terdiri dari:

a) Motif Transaksi

Teori ini pertama kali diusulkan oleh Baumol (1952) dan Miller \& Orr (1966). Motif ini menjelaskan bahwa jika perusahaan dapat mengeluarkan biaya transaksi dengan menggunakan kas daripada melikuidasi aset maka perusahaan akan mendapatkan keuntungan dalam memegang uang tunai secara optimal. Perusahaan akan memiliki lebih banyak kas ketika biaya transaksi tinggi untuk mengubah aset keuangan non tunai untuk menjadi kas. Sebaliknya, perusahaan akan memiliki jumlah kas yang lebih sedikit 
apabila biaya oportunistik dari kas menjadi lebih rendah, terdapat kecenderungan perusahaan menggunakan kas mereka untuk membiayai peluang investasi yang lebih menguntungkan.

b) Motif Berjaga-jaga

Perusahaan memegang kas untuk mengatasi kekurangan kas di masa depan. Perusahaan dengan peluang investasi yang lebih baik menyimpan kas dengan jumlah yang banyak bertujuan untuk mencegahnya guncangan yang merugikan ketika akses ke pasar modal memerlukan biaya yang mahal sehingga perusahaan tetap dapat membiayai kebutuhan investasinya meskipun guncangan perekonomian dan financial distress terjadi.

c) Motif Spekulasi

Perusahaan menyimpan kas digunakan untuk tujuantujuan spekulasi agar mendapatkan keuntungan dari kondisi yang diharapkan. Akan tetapi, pihak manajemen tidak dapat mengakumulasikan jumlah yang diperlukan untuk setiap tujuan, karena jumlah uang yang sama sering kali dapat memenuhi lebih dari satu tujuan.

d) Motif Keagenan

Motif keagenan juga mempunyai pengaruh terhadap motif perusahaan dalam memegang kas. Seperti yang dikemukakan oleh Jensen (1986), manajer mencoba untuk mempertahankan kas yang dimiliki oleh perusahaan daripada melakukan pembayaran kepada pemegang saham ketika perusahaan memiliki peluang investasi yang besar. Manajer cenderung menggunakan kas yang menganggur untuk keuntungan bagi diri mereka sendiri.

\section{Keterbacaan Pengungkapan Naratif dan Cash Holdings}

Beberapa literatur teori telah menguji sejumlah motif untuk menjelaskan keputusan memegang uang dalam perusahaan. Motif tersebut terdiri dari motif agensi (Dittmar \& Mahrt-Smith, 2007); (Harford et al., 2014); (Michael C. Jensen, 1986), motif pencegahan atau berjaga-jaga (Bates et al., 2009) dan motif transaksi. Teori ini menyatakan bahwa perusahaan yang memiliki masalah asimetri informasi akan merasa sulit mendapatkan 
pembiayaan dengan biaya yang lebih murah dan karenanya, harus memegang lebih banyak uang. Pada penelitian ini dihipotesiskan bahwa terdapat hubungan positif antara keterbacaan pengungkapan naratif dan keputusan memegang kas berdasarkan motif agensi dan motif pencegahan.

Berdasarkan motif agensi, kebijakan cash holding perusahaan menunjukkan bahwa manajer lebih memilih untuk memperkuat kas perusahaan, daripada membayar dividen kepada pemegang saham, karena cash holding dapat meningkatkan tingkat aset yang dikendalikan manajer dan memberikan manajer fleksibilitas untuk mengejar tujuan mereka sendiri (Harford et al., 2014). Selain itu, uang tunai mudah diakses oleh manajemen, dan banyak penggunaannya bersifat diskresioner. Oleh karena itu, pemegang saham lebih memilih untuk membatasi akses manajer terhadap uang tunai untuk mengurangi biaya agensi (Jensen, 1986).

Pengungkapan informasi naratif yang lebih panjang dan/atau kurang dapat terbaca meningkatkan tingkat informasi asimetri dan membuat pengawasan kegiatan manajerial semakin sulit dan mahal. Pemegang saham akan memiliki pengetahuan yang kurang tepat tentang kompetensi, upaya dan kinerja manajemen, yang tidak hanya melemahkan pengawasan manajemen, tetapi juga memperburuk konflik agensi antara prinsipal dan agen. Penelitian ini menduga bahwa informasi asimetri dan masalah agensi yang berasal dari pengungkapan yang kurang terbaca, mungkin memotivasi manajer oportunistik menahan lebih banyak uang dan mengalokasikan sumber daya perusahaan untuk melayani diri sendiri.

Hubungan positif antara laporan tahunan yang kurang terbaca dan kebijakan memegang uang perusahan (corporate cash holdings) juga dapat dipertimbangkan mengikuti motif pencegahan. Perusahaan yang memiliki kebutuhan meningkatkan pembiayaan dari luar, akan memegang lebih banyak uang untuk mengatasi guncangan yang merugikan dengan adanya pembiayaan eksternal yang mahal (Almeida et al., 2004). Memegang kas menguntungkan perusahaan dengan mengurangi biaya transaksi, risiko kesulitan keuangan, dan dengan meningkatkan kesempatan untuk memanfaatkan proyek NPV positif, terutama bagi perusahaan dengan kesulitan dalam mengakses pembiayaan eksternal. Pengungkapan 
yang kurang terbaca membuat penyedia modal eksternal memerlukan dan meluangkan lebih banyak waktu sehingga menimbulkan biaya tambahan untuk memproses informasi mengenai penggunaan modal di masa mendatang. Oleh karena itu, pemegang saham (dan pemegang obligasi) cenderung tidak membeli saham (dan obligasi) perusahaan yang memberikan laporan tahunan kurang terbaca. Dengan demikian, berdasarkan motif pencegahan, penelitian ini memprediksi bahwa pengungkapan kurang terbaca membuat perusahaan akses ke modal eksternal sulit dan mahal, yang mendorong perusahaan untuk menyimpan lebih banyak uang tunai.

Selanjutnya, dari aspek risiko pembiayaan kembali terdapat pandangan bahwa perubahan dalam kondisi pasar atau ketidaksempurnaan pasar modal dapat menyebabkan perusahaan mengalami kesulitan atas struktur utang yang jatuh tempo dalam jangka pendek dibanding utang jangka panjang. Untuk mengurangi risiko ini, perusahaan dengan struktur utang jatuh tempo yang lebih pendek cenderung menyimpan lebih banyak uang tunai dan meningkatkan tabungan uang tunai dari arus kas (Harford et al., 2014). Mengingat bahwa pengungkapan naratif yang kurang mudah dibaca menghambat kemampuan kreditor untuk memperkirakan risiko perusahaan, pemberi pinjaman berusaha untuk membatasi eksposur risiko peminjam dan biaya agensi dengan menyediakan pinjaman jangka pendek. Sehingga, berdasarkan argumen risiko pembiayaan kembali, pengungkapan informasi naratif yang kurang dapat dibaca juga dapat meningkatkan kepemilikan kas perusahaan. Oleh karena itu, berdasarkan argumen di atas, dikembangkan hipotesis berikut:

$$
\begin{aligned}
\mathrm{H}_{1} \text { : } & \text { Perusahaan } \\
& \text { pengungkapan narasi kurang } \\
& \text { terbaca dalam laporan tahunan } \\
& \text { akan memegang lebih banyak } \\
& \text { kas. }
\end{aligned}
$$

\section{METODE}

\section{Desain Penelitian}

Penelitian ini merupakan studi empiris yang dilakukan untuk menganalisis hubungan keterbacaan pengungkapan informasi naratif laporan tahunan dengan kebijakan memegang kas (cash holdings) perusahaan. Penelitian ini dilakukan pada perusahaan yang terdaftar di Bursa Efek Indonesia (BEI). Pada Gambar 1 di bawah ini ditunjukkan model rerangka penelitian. 


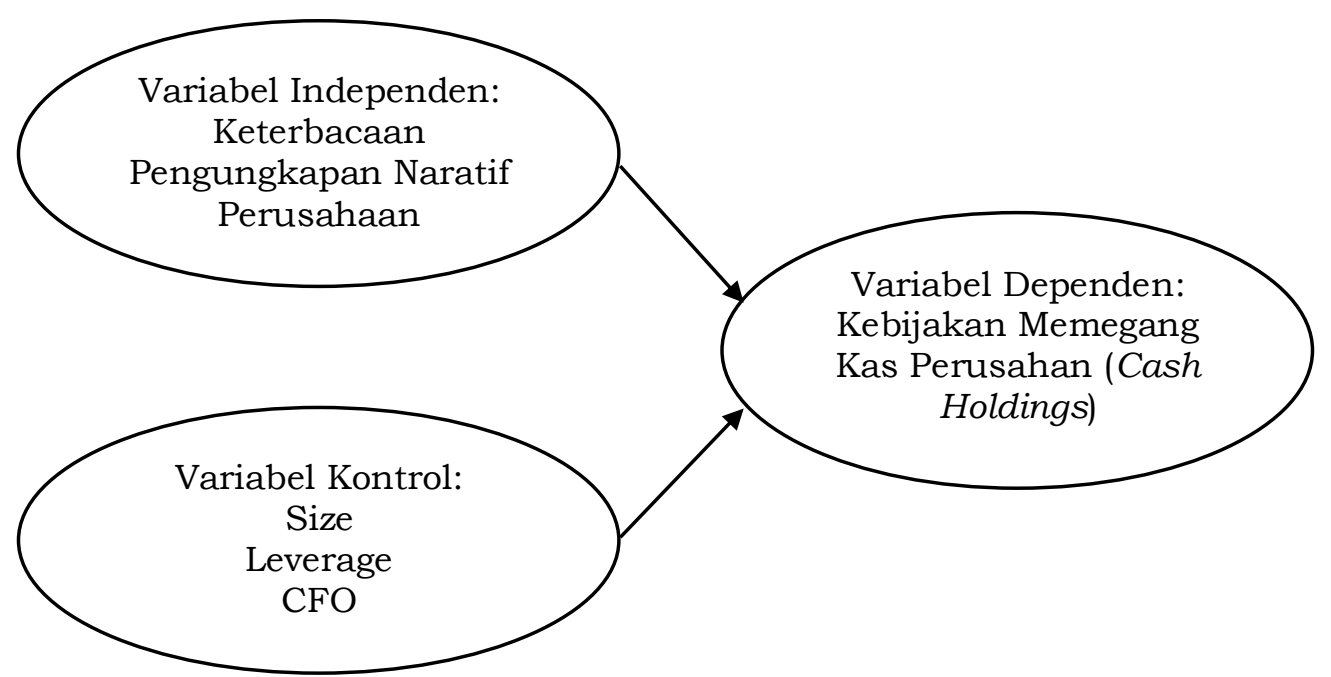

Gambar 1: Rerangka Konseptual Desain Penelitian

\section{Jenis dan Sumber Data}

Jenis data yang digunakan dalam penelitian ini yaitu data sekunder. Sumber data yang digunakan dalam penelitian ini adalah data yang berasal dari laporan tahunan perusahaan yaitu kebijakan memegang kas perusahan (cash holdings) yaitu berupa laporan MD\&A (management discussion and analysis) dan data kas dari laporan keuangan perusahaan. Laporan MD\&A yang dianalis adalah laporan MD\&A berbahasa Indonesia, karena laporan berbahasa Inggris diyakini hanya berupa translasi dari laporan berbahasa Indonesia, bukan laporan yang disiapkan dan disajikan secara terpisah. Data ini dikumpulkan untuk tahun 2015 sampai tahun 2017. Data mengenai laporan tahunan tersebut diperoleh dari situs resmi BEI yaitu www.idx.co.id serta dari situs resmi perusahaan sampel.

\section{Populasi dan Sampel}

Populasi dalam penelitian ini adalah seluruh perusahaan yang terdaftar di Bursa Efek Indonesia (BEI) dari tahun 2015 sampai tahun 2017. Periode penelitian ini dari tahun 2015 sampai 2017 dipilih dalam rangka menjamin ketersediaan data laporan tahunan yang umumnya bisa diakses secara bebas untuk tiga tahun kebelakang, baik dari website idx.co.id atau website masing-masing perusahaan. Pemilihan sampel dilakukan berdasarkan kriteria tertentu. Berikut disajikan kriteria pemilihan sampel pada penelitian ini (Tabel 1). 
Tabel 1. Kriteria Pemilihan Sampel

\begin{tabular}{ll}
\hline Kriteria pemilihan sampel & Jumlah \\
\hline Perusahaan yang terdaftar pada BEI tahun 2017 & 671 \\
Perusahaan yang bergerak pada sektor keuangan & $(87)$ \\
Perusahaan yang baru terdaftar pada BEI tahun 2017 & $(52)$ \\
Perusahaan yang tidak konsisten terdaftar pada BEI dari tahun & $(174)$ \\
2015-2017 & $(113)$ \\
Perusahaan yang tidak memiliki data keuangan yang lengkap & 245 \\
\hline Jumlah perusahaan & 735 \\
\hline Jumlah sampel awal = 245 x 3 tahun & $(23)$ \\
\hline$\quad$ Data outlier & $\mathbf{7 1 2}$ \\
\hline
\end{tabular}

\section{Model Penelitian}

Untuk menguji pengaruh keterbacaan pengungkapan naratif laporan tahunan dengan kebijakan memegang kas (cash holdings) maka dijabarkan model penelitian berikut:

\section{$\operatorname{Cash}_{\mathrm{t}+1} / \mathbf{N A}_{\mathrm{i}, \mathrm{t}}=\mathbf{a}_{0}+\beta_{1} \operatorname{Read}_{\mathrm{i}, \mathrm{t}}+\boldsymbol{\beta}_{2} \mathbf{S I Z E}_{\mathrm{i}, \mathrm{t}}$ $+\beta_{2}$ Leverage $_{i, t}+\beta_{4}$ CFO $_{i, t}+\varepsilon$}

\section{Keterangan:}

Cash $_{, t+1}=$ saldo kas dan surat berharga perusahaan i, pada tahun $\mathrm{t}+1$

$\operatorname{Read}_{i, t}=$ keterbacaan pengungkapan informasi naratif perusahaan $\mathrm{i}$ tahun $\mathrm{t}$. $\mathrm{SIZE}_{\mathrm{i}, \mathrm{t}}=$ ukuran perusahaan yang dihitung berdasarkan total nilai asset perusahaan i pada tahun $\mathrm{t}$

Leverage $_{\mathrm{i}, \mathrm{t}}=$ total liabilitas dibagi total asset perusahaan i pada tahun $\mathrm{t}$

$\mathrm{CFO}_{i, \mathrm{t}}=$ arus kas operasi dibagi total asset

$\mathrm{a}=$ Konstanta

$\mathrm{e}=$ Standar error

Pada model penelitian terlihat variabel dependen penelitian ini menggunakan nilai kas masa datang $\left(\mathrm{Cash}_{\mathrm{t}+1}\right)$, karena pengaruh keterbacaan laporan tahunan yang diterbitkan akhir tahun sekarang, akan diekpektasi akan terlihat pada kebijakan kas mendatang. Selain menguji pengaruh keterbacaan laporan, model penelitian ini juga mengikut sertakan beberapa variabel karakteristik perusahaan yaitu, ukuran perusahaan (size), utang perusahaan (leverage), dan arus kas operasi perusahan (CFO) sebagai variabel kontrol. Ketiga variabel kontrol ini dijustifikasi merupakan variabelvariabel yang akan sangat mempengaruhi kebijakan kas perusahan, didasarkan pada motif yang melatarbelakangi kas dipegang perusahaan.

\section{Pengukuran Variabel}

Cash holdings

Variabel dependen penelitian ini adalah kas yang dipegang (cash holdings) perusahaan. Penelitian ini menggunakan empat ukuran kas yang dipegang perusahaan dalam 
analisis yaitu kas dan surat berharga yang diskalakan dengan total aset (CASH/TA), kas dan surat berharga yang diskalakan dengan Aset bersih (yaitu, total aset dikurangi kas dan sekuritas yang dapat dijual) (CASH/NA), logaritma dari kas dan surat berharga (Log CASH). Penelitian ini menggunakan data absolut dari kas, bukan kelebihan kas karena diyakini lebih menggambarkan kebijakan perusahaan tentang seberapa besar jumlah kas yang dipegang perusahaan per tahun, dibanding kelebihan kas yang cenderung menggambarkan arus atau peredaran kas. Ukuran atas kebijakan kas yang dipegang ini telah digunakan dalam beberapa studi sebelumnya secara ekstensif (misalnya oleh, (Acharya et al., 2013); (Hasan \& Habib, 2020); (Harford et al., 2014).

\section{Keterbacaan Laporan Tahunan}

Variabel independen dalam penelitian ini adalah keterbacaan. (Dale \& Chall, 1948) mendefinisikan keterbacaan sebagai jumlah total semua elemen dalam dokumen tercetak yang dapat membuat sekelompok pembaca memahami dokumen tersebut, membacanya dalam kecepatan yang optimal dan dokumen tersebut menarik untuk dibaca. Keterbacaan diukur dengan menggunakan indeks Fog (Biddle et al., 2009); (Ertugrul et al., 2017); (Li, 2008). Formula keterbacaan dirancang untuk memprediksi tingkat kesulitan pembaca terhadap suatu tulisan.

Pengukuran Indek FOG ini berdasarkan kata "Foggy" atau kabut. Adapun perhitungan keterbacaan Indeks FOG yaitu:

GFScore $=0,4 \times\left(\left(\frac{\text { Words }}{\text { Sentences }}\right)+100 \times\left(\frac{\text { Complexwords }}{\text { Words }}\right)\right)$ Indeks FOG bergantung pada jumlah rata kata per kalimat dan persentase kata kompleks dalam sebuah dokumen untuk mengukur keterbacaan dokumen. Oleh karena itu, semakin tinggi tingkat FOG index, yang semakin rendah keterbacaan dokumen atau semakin sulit suatu tulisan dibaca dan dipahami. Status keterbacaan untuk pengukuran ini yaitu: Fog $\geq 18$ berarti teks tidak dapat dibaca; 14-18 (sulit); 12-14 (ideal); 1012 (dapat diterima) dan 8-10 (kekanak-kanakan).

\section{Variabel Kontrol}

Penelitian ini menggunakan tiga variabel kontrol untuk mempertimbangkan variabel karakteristik perusahaan yaitu ukuran perusahaan (size), leverage, dan arus kas operasi (CFO). Ukuran perusahaan (size) diukur dengan nilai logaritma dari total asset perusahaan. Leverage diukur dengan rasio total kewajiban dibagi dengan total asset, sedangkan 
arus kas operasi dihitung dari arus kas bersih operasi pada laporan arus kas perusahaan.

\section{Teknik Analisis Data}

Analisis data merupakan bagian dari proses pengujian data setelah tahap pemilihan dan pengumpulan data penelitian dilakukan. Tahapan dalam melakukan analisis data penelitian adalah sebagai berikut: uji asumsi klasik, analisis statistic deskriptif, uji korelasi antar variabel dan analisis regresi berganda.

\section{HASIL DAN PEMBAHASAN}

Pembahasan pada bagian ini akan dimulai dengan menyajikan dan menganalisis statistik deskriptif data penelitian, dilanjutkan dengan pemaparan dan pembahasan hasil temuan pengujian model penelitian.

\section{Statistik Deskriptif}

Analisis statistik deskriptif bertujuan untuk memberikan gambaran umum mengenai profil sampel dan variabel penelitian. Tabel 2 berikut ini menunjukkan bahwa indek FOG yang merupakan ukuran keterbacaan laporan tahunan menunjukkan rentang nilai dari skor 5.70 paling minimum sampai dengan 14.8 paling tinggi, dengan nilai rerata sebesar 9.34. Sebagaimana telah dijelaskan pada pengukuran variabel, bahwa status keterbacaan untuk pengukuran indek FOG dapat diklasifikasi sebagai berikut: FOG $\geq 18$ berarti teks tidak dapat dibaca; 14-18 (sulit); 12-14 (ideal); 10-12 (dapat diterima) dan 8-10 (sangat mudah). Jadi, semakin tinggi indeks FOG semakin sulit suatu tulisan untuk dibaca dan dipahami. Analisis statistik deskriptif ini menunjukkan bahwa laporan MD\&A perusahaan memiliki tingkat keterbacaan yang menyebar dari rentang sangat mudah sampai dengan sulit, dengan rata-rata sangat mudah untuk dibaca.

$$
\text { Selanjutnya, } \mathrm{Cash}_{\mathrm{t}+1} / \mathrm{Na}_{\mathrm{t}+1} \text { yang }
$$
merupakan rasio yang menunjukkan proporsi kas yang dipegang perusahaan dibanding total asset setelah dikurang kas perusahaan tahun mendatang menunjukkan nilai minimum sebesar 0,00 dan maksimum 0,42, dengan rata-rata sebesar 0,0949. Data statistik deskriptif rasio kas ini menunjukkan bahwa terdapat perusahaan yang sangat sedikit memegang uang, namun disisi lain juga terdapat perusahaan yang memegang kas dengan proporsi hampir setengah dari nilai total asset. Secara rata-rata, perusahaan sampel memegang uang hampir sebesar $10 \%$ dari total asset 
Tabel 2. Statistik Deskriptif

\begin{tabular}{lrrrr}
\hline \multicolumn{1}{c}{ Variabel } & \multicolumn{1}{c}{ Min } & \multicolumn{1}{c}{ Max } & Mean & \multicolumn{1}{c}{ Std. Dev } \\
\hline Cash $_{\mathrm{t}+1} / \mathrm{NA}_{\mathrm{t}+1}$ & 0,00 & 0,42 & 0,0949 & 0,0926 \\
FOG & 5,7 & 14,8 & 9,3434 & 1,2813 \\
Size & 3,5386 & 7,3392 & 5,4016 & 0,6821 \\
Leverage & 0,0084 & 5,0733 & 0,5008 & 0,3971 \\
CFO & $-0,0373$ & 0,6591 & 0,0080 & 0,0274
\end{tabular}

Sumber: data sekunder yang diolah (2020)

Tabel 3. Korelasi Antar Variabel

\begin{tabular}{|c|c|c|c|c|c|}
\hline $\begin{array}{c}\text { Pearson } \\
\text { Corr }\end{array}$ & Cash/NA & FOG & Size & Leverage & CFO \\
\hline $\operatorname{Cash}_{\mathrm{t}+1} / \mathrm{NA}_{\mathrm{t}+1}$ & 1.000 & $\begin{array}{r}.088 \\
(0.06)\end{array}$ & $\begin{array}{r}.123 \\
(0,000)\end{array}$ & $\begin{array}{r}-.240 \\
(0,000)\end{array}$ & $\begin{array}{r}.187 \\
(0,000)\end{array}$ \\
\hline FOG & $\begin{array}{r}.088 \\
(0,06)\end{array}$ & 1.000 & $\begin{array}{r}.030 \\
(0,109)\end{array}$ & $\begin{array}{r}-.021 \\
(0,149)\end{array}$ & $\begin{array}{r}.067 \\
(0,021)\end{array}$ \\
\hline Size & $\begin{array}{r}.123 \\
(0,000)\end{array}$ & $\begin{array}{r}.030 \\
(0,109)\end{array}$ & 1.000 & $\begin{array}{r}.202 \\
(0,000)\end{array}$ & $\begin{array}{r}.018 \\
(0,160)\end{array}$ \\
\hline Leverage & $\begin{array}{r}-.240 \\
(0,0000\end{array}$ & $\begin{array}{r}-.021 \\
(0,149)\end{array}$ & $\begin{array}{r}.202 \\
(0,000)\end{array}$ & 1.000 & $\begin{array}{r}-.095 \\
(0,003)\end{array}$ \\
\hline $\mathrm{CFO} / \mathrm{TA}$ & $\begin{array}{r}.187 \\
(0,000) \\
\end{array}$ & $\begin{array}{r}.067 \\
(0,021) \\
\end{array}$ & $\begin{array}{r}.018 \\
(0,160) \\
\end{array}$ & $\begin{array}{r}-.095 \\
(0,003) \\
\end{array}$ & 1.000 \\
\hline
\end{tabular}

\section{Korelasi Antar Variabel}

Analisis atas korelasi antar variabel diperlukan untuk melihat keterkaitan antar variabel penelitian yang diuji. Analisis ini dapat dilakukan dengan menggunakan nilai pearson correlation yang ditampilkan pada tabel 3. Berdasarkan tabel 3 terlihat bahwa variabel FOG memiliki korelasi dengan Cash/NA dengan level signifikansi $10 \% \quad($ sig=0,06). Variabel FOG terlihat juga memiliki hubungan dengan arus kas operasi, namun tidak memiliki hubungan dengan ukuran perusahaan dan proporsi hutang perusahaan.

\section{Hasil Pengujian Hipotesis}

Seperti yang telah dijelaskan pada bab-bab sebelumnya, penelitian ini bertujuan untuk menguji pengaruh keterbacaan informasi naratif laporan tahunan terhadap kebijakan perusahaan dalam memegang kas. Berdasarkan pengujian model regresi liner berganda yang digunakan, diperoleh bukti empiris model keseluruhan variabel penelitian berpengaruh signifikan (Lampiran Ouput SPSS: ANOVA) dengan nilai $\mathrm{F}$ test sebesar 309,128 dengan signifikansi sebesar 0.000. Nilai determinasi seluruh variabel pengujian 
Tabel 4. Hasil Pengujian Hipotesis

\begin{tabular}{lrrr}
\hline \multicolumn{1}{c}{ Variabel } & Koefisien & t-value & \multicolumn{1}{c}{ Sig } \\
\hline Konstanta & -1.889 & -8.210 & .000 \\
FOG & .033 & 1.961 & .050 \\
Size & 1.090 & 34.774 & .000 \\
Leverage & -.298 & -5.553 & .000 \\
CFO & 1.534 & 1.967 & .050 \\
\hline
\end{tabular}

Sumber: Output SPSS (2020)

yang ditunjukkan oleh nilai Adjusted R2 memperlihatkan nilai sebesar 0,636. Secara statistik nilai ini dapat diartikan bahwa variabel-variabel independen yang dimasukkan dalam penelitian ini dapat menjelaskan sebesar 63,6\% variasi dari kebijakan perusahaan dalam memegang kas.

Adapun hasil pengujian hipotesis penelitian atas pengaruh keterbacaan laporan tahunan terhadap kas yang dipegang tahun mendatang, dapat kita lihat pada tabel 4. Hasil pengujian penelitian ini menunjukkan bahwa variabelvariabel karakteristik perusahaan yang merupakan variabel kontrol penelitian berpengaruh signifikan terhadap kas yang dipegang perusahaan. Ukuran perusahaan (size) ditemukan berpengaruh positif signifikan terhadap kas yang dipegang perusahaan dengan nilai koefisien sebesar 1,090, t-value 34,774 dan level signifikansi 1\% (sig = 0,000). Arah koefisien yang bertanda positif menggambarkan bahwa semakin besar perusahaan, semakin banyak kas yang dipegang perusahaan. Selain ukuran perusahaan, variabel leverage juga terbukti memiliki pengaruh terhadap kas yang dipegang perusahaan. Nilai koefisien leverage yaitu sebesar 0,298 dengan t-value sebesar $-5,553$ dan signifikan pada level $a=1 \%$, dapat diartikan bahwa pengaruh negatif leverage terhadap kebijakan kas yang dipegang perusahaan sangat kuat. Arah pengaruh negatif leverage ini dapat diartikan bahwa peningkatan leverage perusahaan akan menyebabkan kas perusahaan semakin turun dalam upaya menyelesaikan pelunasan hutang perusahaan tersebut. Terakhir, variabel kontrol yang diuji dalam penelitian ini adalah arus kas operasi perusahaan. Hasil pengujian penelitian ini menunjukkan bahwa arus kas operasi memiliki pengaruh positif signifikan terhadap kas yang dipegang perusahaan. Dengan koefisien sebesar 1,534 t-value 1,967 
dengan signifikansi $5 \%(\operatorname{sig}=0,050)$. Dapat dinyatakan bahwa pengaruh arus kas operasi kuat dan searah dengaan kebijakan kas yang dipegang perusahaan.

Dari tabel 4 diatas, dapat dilihat bahwa varibel FOG berpengaruh signifikan terhadap Casht $+1 / \mathrm{Nat}+1$ dengan nilai koefiesien sebesar, $t$ value sebesar 0,033 yang menunjukkan signifikan pada level signifikansi $5 \%(\mathrm{sig}=0,050)$. Temuan ini artinya memberikan dukungan terhadap hipotesis 1 yang dibangun, bahwa keterbacaan laporan tahunan akan mempengaruhi kebijkan kas yang dipegang perusahaan tahun mendatang. Koefien FOG yang bernilai positif 0,033, menggambarkan bahwa setiap peningkatan indek FOG, artinya laporan makin sulit dibaca, maka perusahaan akan memegang uang semakin banyak. Temuan ini secara teori sejalan dengan motif precautionary dan motif agensi yang mendasari kebijakan perusahaan dalam memegang kas.

Berdasarkan teori precautionary motif, perusahaan yang memiliki masalah asimetri informasi akan merasa sulit mendapatkan pembiayaan dengan biaya yang lebih murah dan karenanya, harus memegang lebih banyak kas. Kesulitan untuk mendapatkan sumber pembiayaan dan pembeban biaya modal yang tinggi, akan mendorong perusahaan melakukan pembiayaan internal dengan kas yang dipegang perusahaan.

Temuan penelitian ini juga dapat dijelaskan dengan motif agensi yang melandasi kebijakan perusahaan memegang kas. Berdasarkan motif agensi, pengungkapan informasi naratif yang lebih panjang dan/atau kurang dapat dibaca, meningkatkan tingkat asimetri informasi dan membuat pengawasan kegiatan manajerial semakin sulit dan mahal. Pemegang saham akan memiliki pengetahuan yang kurang tepat tentang kompetensi, upaya, dan kinerja manajemen, yang tidak hanya melemahkan pengawasan terhadap manajemen, tetapi juga memperburuk konflik agensi antara prinsipal dan agen. Melemahnya pengawasan dan buruknya konflik keagenan ini akan memberi ruang bagi manajer untuk menyimpan kas lebih banyak demi kepentingan sendiri.

Temuan penelitian ini sejalan dengan temuan penelitian (Hasan \& Habib, 2020), (Ertugrul et al., 2017), dan (Harford et al., 2014). (Hasan \& Habib, 2020) menemukan bahwa perusahaan dengan laporan tahunan yang kurang terbaca memiliki tingkat kas yang jauh lebih tinggi daripada 
perusahaan dengan lebih mudah dibaca. Mereka juga menemukan bahwa hubungan antara keterbacaan laporan tahunan dan kepemilikan kas lebih jelas bagi perusahaan dengan lebih banyak masalah agensi, kendala pembiayaan, dan risiko refinancing. Hasil penelitian ini juga sesuai dengan penelitian (Ertugrul et al., 2017) yang menemukan bahwa kreditur mau memperpanjang pinjaman jangka pendek kepada perusahaan dengan pengungkapan narasi yang dapat dibaca. Begitu juga dengan penelitian (Harford et al., 2014) menemukan perusahaan dengan risiko refinancing, memegang lebih banyak uang tunai untuk menghindari tekanan keuangan dan potensi kebangkrutan.

\section{KESIMPULAN, IMPLIKASI DAN KETERBATASAN PENELITIAN}

Penelitian ini bertujuan untuk menguji pengaruh keterbacaan laporan tahunan terhadap kebijakan perusahaan dalam memegang kas. Hasil penelitian ini menunjukkan bahwa keterbacaan laporan tahunan memiliki pengaruh terhadap jumlah kas yang dipegang perusahan. Semakin sulit laporan tahunan dibaca, maka semakin banyak kas yang dipegang oleh perusahaan. Hasil ini sesuai dengan penelitian Hasan dan (Hasan \& Habib, 2020), (Ertugrul et al., 2017) dan (Harford et al., 2014). Penelitian ini berkontribusi dalam menyatukan dua aliran riset yang berbeda yaitu tentang keterbacaan pengungkapan kebijakan perusahaan dan bahasa. Penelitian ini menunjukkan bahwa peningkatan keterbacaan pengungkapan perusahaan bisa menjadi jalan penting untuk mengurangi kebijakan memegang kas yang bagi perusahaan. Secara keseluruhan, hasil riset ini menunjukkan pemahaman tentang bagaimana keterbacaan pengungkapan perusahaan dikaitkan dengan hasil keuangan. Sehingga hasil berimplikasi terhadap kebijakan internal perusahaan.

Penelitian memiliki beberapa keterbatasan yang kemudian bisa menjadi rekomendasi penelitian lanjutan: Pertama, data yang digunakan dalam penelitian ini masih terbatas, sehingga perlu penambahan data. Kedua, penelitian ini menggunakan indeks FOG untuk mengukur keterbacaan laporan tahunan, yang mana terdapat alternatif lain pengukuran keterbacan informasi naratif yang lain seperti Flesch Reading Ease, Flesch Kincaid, panjang dokumen, yang dapat dijadikan dasar untuk melakukan analisis sensitivitas penelitian. 


\section{REFERENSI}

Acharya, V. V., Almeida, H., \& Campello, M. (2013). Aggregate risk and the choice between cash and lines of credit. Journal of Finance. https://doi.org/10.1111/jofi.12 056

Almeida, H., Campello, M., \& Weisbach, M. S. (2004). The cash flow sensitivity of cash. In Journal of Finance. https://doi.org/10.1111/j.15406261.2004.00679.x

Bates, T. W., Kahle, K. M., \& Stulz, R. M. (2009). Why do U.S. firms hold so much more cash than they used to? Journal of Finance. https://doi.org/10.1111/j.15406261.2009.01492.x

Baumol, W. J. (1952). The transactions demand for cash: An inventory theoretic approach. Quarterly Journal of Economics. https://doi.org/10.2307/ 18821 04

Biddle, G. C., Hilary, G., \& Verdi, R. S. (2009). How does financial reporting quality relate to investment efficiency? Journal of Accounting and Economics. https://doi.org/10.1016/j.jaccec o.2009.09.001

Bonsall, S. B., \& Miller, B. P. (2017). The impact of narrative disclosure readability on bond ratings and the cost of debt. Review of Accounting Studies. https: / / doi.org/10.1007/s11142 $-017-9388-0$

Connatser, B. R. (1999). Last rites for readability formulas in technical communication. Journal of Technical Writing and Communication.

https: / / doi.org/10.2190/6EWHJ5C5-AV1X-KDGJ
Dale, E., \& Chall, J. S. (1948). A formula for predicting readability. Educational Research Bulletin.

Dittmar, A., \& Mahrt-Smith, J. (2007). Corporate governance and the value of cash holdings. Journal of Financial Economics. https://doi.org/10.1016/j.jfinec 0.2005 .12 .006

DuBay, W. (2004). The Principles of Readability. Online Submission.

Ertugrul, M., Lei, J., Qiu, J., \& Wan, C. (2017). Annual Report Readability, Tone Ambiguity, and the Cost of Borrowing. Journal of Financial and Quantitative Analysis.

https://doi.org/10.1017/S0022 109017000187

Han, S., \& Qiu, J. (2007). Corporate precautionary cash holdings. Journal of Corporate Finance. https://doi.org/10.1016/j.jcorpf in.2006.05.002

Harford, J., Klasa, S., \& Maxwell, W. F. (2014). Refinancing risk and cash holdings. Journal of Finance. https://doi.org/10.1111/jofi.12 133

Hasan, M. M., \& Habib, A. (2020). Readability of narrative disclosures, and corporate liquidity and payout policies. International Review of Financial Analysis.

https://doi.org/10.1016/j.irfa.2 020.101460

Huang, P., \& Zhang, Y. (2012). Does enhanced disclosure really reduce agency costs? Evidence from the diversion of corporate resources. In Accounting Review. https://doi.org/10.2308/accr10160 
Klare, G. R. (1963). Assessing readability. Reading Research Quarterly, 110, 63-102.

Lang, M., Stice-Lawrence, L. (2015). Textual analysis and internasional financial reporting: Large sample evidence. Journal of Accounting and Economic, 60(2), 110-135.

Lehavy, R., Li, F., \& Merkley, K. (2011). The effect of annual report readability on analyst following and the properties of their earnings forecasts. Accounting Review. https: / /doi.org/10.2308/accr.00 000043

Li, F. (2008). Annual report readability, current earnings, and earnings persistence. Journal of Accounting and Economics.

https://doi.org/10.1016/j.jaccec o.2008.02.003

Lo, K., Ramos, F., \& Rogo, R. (2017). Earnings management and annual report readability. Journal of Accounting and Economics.

https://doi.org/10.1016/j.jaccec o.2016.09.002

Loughran, T., \& Mcdonald, B. (2011). When Is a Liability Not a Liability? Textual Analysis, Dictionaries, and 10-Ks. Journal of Finance. https://doi.org/10.1111/j.15406261.2010.01625.x

Michael C. Jensen. (1986). Agency Costs of Free Cash Flow, Corporate Finance, and Takeovers Agency Costs of Free Cash Flow, Corporate Finance, and Takeovers. American Economic Review.

Miller, M. H., \& Orr, D. (1966). A model of the demand for money by firms. Quarterly Journal of Economics.

https://doi.org/10.2307/18807 28 